\title{
Equilibrium, Kinetics, and Thermodynamics of the Biosorption of Zn(II) from Aqueous Solution Using Powdered Cow Hooves
}

\author{
Ilesanmi Osasona, ${ }^{1}$ Olubode O. Ajayi, ${ }^{2}$ and Albert O. Adebayo ${ }^{2}$ \\ ${ }^{1}$ Department of Chemical Sciences, Afe Babalola University, PMB 5454, Ado-Ekiti 360101, Nigeria \\ ${ }^{2}$ Department of Chemistry, Federal University of Technology, PMB 704, Akure 340252, Nigeria
}

Correspondence should be addressed to Ilesanmi Osasona; oosasona@yahoo.com

Received 24 June 2013; Accepted 17 July 2013

Academic Editors: I. Anusiewicz, H. Reis, and E. B. Starikov

Copyright (C) 2013 Ilesanmi Osasona et al. This is an open access article distributed under the Creative Commons Attribution License, which permits unrestricted use, distribution, and reproduction in any medium, provided the original work is properly cited.

\begin{abstract}
The capability of cow hoof $(\mathrm{CH})$ to remove $\mathrm{Zn}$ (II) from aqueous solution under the influence of sorbent size, solution $\mathrm{pH}$, contact time, and sorbent dosage was investigated through batch studies. Equilibrium studies were conducted at three different temperatures $(298,308$, and $318 \mathrm{~K})$ by contacting different concentrations of $\mathrm{Zn}$ (II) solution with a known weight of cow hoof. The biosorption of $\mathrm{Zn}$ onto cow hoof was found to increase with increase in the mass of sorbent used while the biosorption efficiency was found to decrease with increase in sorbent particle size. The optimum conditions of $\mathrm{pH} 4$ and contact time of 60 minutes were required for maximum removal of $\mathrm{Zn}$ (II) by cow hoof (mesh size $212 \mu \mathrm{m}$ ). The equilibrium data were modelled using Langmuir, Freundlich, and Dubinin-Radushkevich (D-R) isotherm models. The data were best fitted by Langmuir model. The kinetic data were analysed using Lagergren kinetic equations and these were well fitted by the pseudo-second-order kinetic model. The thermodynamic parameters showed that the biosorption process was feasible, spontaneous, and endothermic.
\end{abstract}

\section{Introduction}

Water is an essential life-sustaining natural resource and as such, its fitness for life sustenance should be constantly maintained and preserved. Unfortunately, heavy metals and other pollutants generated from different industrial and agricultural activities constantly put the purity and life-sustaining ability of this important natural resource under threat. The threat generated by the presence of heavy metals becomes particularly worrisome because of their nonbiodegradability, toxicity, persistency, and bioaccumulation tendency [1-3]. These metals have been implicated in causing health challenges such as accumulative poisoning, cancer, brain damage, lung damage, and hepatic and renal damage $[4,5]$. Zinc is a trace element that is essential for human health. It is important for the physiological functions of living tissues and regulates many biochemical processes. But excessive ingestion of zinc, especially at levels of $100-500 \mathrm{mg} /$ day, can bring about serious health problems, which include stomach cramps, skin irritations, vomiting, nausea, and anaemia $[1,6]$.
There are strict environmental regulations in most developed and developing countries with regard to contaminants discharged from industrial operations. This means that industries need to develop on-site or in-plant facilities to their own effluents and minimize the contaminant concentrations to acceptable limits prior to their discharge [7]. This necessity has seriously enhanced the demand for new technologies for metal removal from wastewater [8]. A number of technologies have been developed to remove toxic heavy metals from industrial wastewater. These include reduction and precipitation, coagulation, ion exchange, reverse osmosis, and evaporation. But most of these treatment technologies have their attendant limitations which include high chemical demand, high capital and operational cost, and generation of toxic sludge or other secondary wastes. In addition, these methods are ineffective at low metal concentrations, particularly in the range of 1-100 $\mathrm{mg} / \mathrm{L}$ [9]. Therefore, there is a need for a cost effective treatment method that is capable of removing heavy metals from solution even at low metal concentrations. 
Biosorption seems to be the answer to this important industrial demand based on the following advantages: low cost, good efficiency, minimization of chemical and biological sludge, regeneration of biosorbent, and possibility of metal recovery $[10,11]$. Some of the biosobents that have been exploited for the removal of $\mathrm{Zn}$ from aqueous solution include marine green macroalga Chaetomorpha linum [1], biosolids [11], Fontinalis antipyretica [12], marine algal biomass [13], metal imprinted chitosan [14], dried animal bones [15], chitosan [16], maize cob and husk [17], Algerian sheep hoof [18], and waste tea leaves [19].

Cow hoof is an inedible spare part of cows which can be obtained free-of-charge from local abattoirs in Nigeria. Thousands of cow hooves are thrown into dumpsites in various abattoirs in Nigeria every day thereby constituting environmental nuisance. Cow hooves are known to contain an insoluble protein called keratin. The presence of keratin in cow hooves can enhance its biosorption capacity since amino and carboxylic functional groups have been identified as parts of the functional groups that are responsible for high metal removal efficiency of biomaterials [20]. Therefore, this study was targeted at investigating the feasibility of using cow hooves as a low-cost adsorbent for the removal of zinc from aqueous solution. The influence of $\mathrm{pH}$, contact time, biosorbent particle size, biosorbent mass, and initial $\mathrm{Zn}$ (II) concentration on the biosorption property of cow hoof was also investigated. The equilibrium data obtained were analysed and modelled using Langmuir, Freundlich, and Dubinin-Radushkevich (D-R) isotherm models.

\section{Experimental}

2.1. Materials. Cow hooves were obtained from a local abattoir along Ekiti State University Road, Ado-Ekiti, Nigeria. The hooves were thoroughly washed with distilled water and sun dried for a month. After drying, the hooves were again washed with distilled water and dried in an oven maintained at a temperature of $105^{\circ} \mathrm{C}$. The oven-dried hooves were later ground and sieved using sieve of mesh sizes $212 \mu \mathrm{m}$, $425 \mu \mathrm{m}$, and $850 \mu \mathrm{m}$. A stock solution containing $1000 \mathrm{mgL}^{-1}$ of $\mathrm{Zn}$ (II) was prepared by dissolving $4.39 \mathrm{~g}$ of analytical grade $\mathrm{ZnSO}_{4} \cdot 7 \mathrm{H}_{2} \mathrm{O}$ in a $1 \mathrm{~L}$ standard flask. This was made to mark with distilled water. Standard solutions of different concentrations were later prepared from this stock.

2.2. Biosorption Studies. Biosorption experiments were carried out through batch process in $150 \mathrm{~mL}$ conical flasks containing $50 \mathrm{~mL} \mathrm{Zn(II)} \mathrm{solution} \mathrm{using} \mathrm{a} \mathrm{thermostatic} \mathrm{water}$ bath shaker operated at a constant speed. The influence of $\mathrm{pH}$ and mass of $\mathrm{CH}$ on the biosorption process was investigated by equilibrating $0.5 \mathrm{~g}$ of $\mathrm{CH}$ (particle size of $212 \mu \mathrm{m}$ ) in a series of conical flasks, containing $50 \mathrm{mgL}^{-1}$ of $\mathrm{Zn}$ (II) solution with $\mathrm{pH}$ ranging from 2.0 to 6.0 and with biosorbent mass ranging from 0.3 to $2.0 \mathrm{gL}^{-1}$, respectively. The effect of contact time and $\mathrm{CH}$ particle size on the removal of $\mathrm{Zn}$ (II) was conducted at different contact times ranging from 0 to 120 minutes and different particle sizes of $212 \mu \mathrm{m}, 425 \mu \mathrm{m}$, and $850 \mu \mathrm{m}$, respectively, using $50 \mathrm{mgL}^{-1} \mathrm{Zn}$ (II) solution. All experiments were

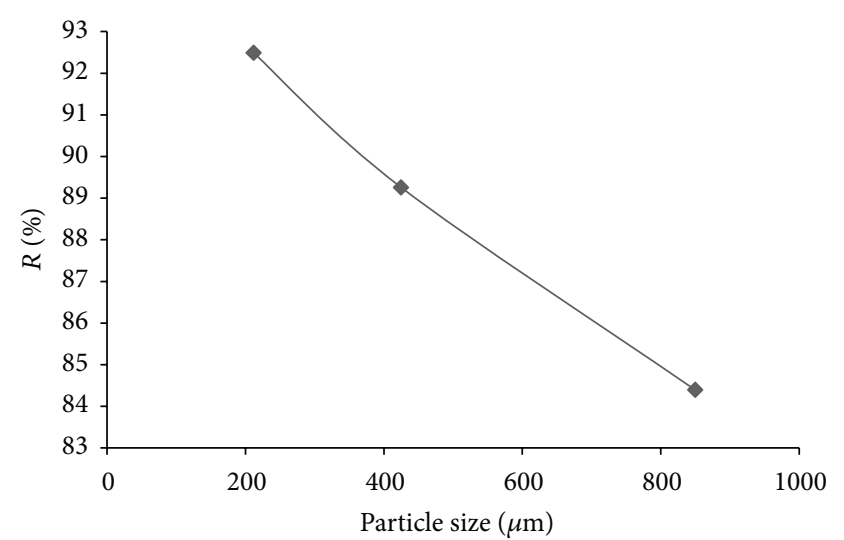

FIGURE 1: Effect of particle size on the sorption of zinc onto cow hoof.

carried out at $298 \mathrm{~K}$. The mixture of the biosorbent and the solution was centrifuged after agitation and the concentration of metal ion present in the supernatant was determined using atomic absorption spectrometer (AAS). The amount of metal ions adsorbed per unit mass of biosorbent was determined according to the following equation:

$$
q_{e}=\frac{\left(C_{0}-C_{e}\right) V}{m}
$$

where $m$ is the mass of $\mathrm{CH}(\mathrm{g}), V$ is the volume of the solution (L), $C_{0}$ is the initial concentration of metal $\left(\mathrm{mgL}^{-1}\right), C_{e}$ is the equilibrium concentration of the adsorbate in the liquid phase $\left(\mathrm{mgL}^{-1}\right)$, and $q_{e}$ is the amount of metal adsorbed at equilibrium $\left(\mathrm{mgg}^{-1}\right)$. The percentage removal $(\% R)$ of zinc was calculated using the following expression:

$$
\% R=\frac{\left(C_{0}-C_{e}\right) \times 100}{C_{0}} .
$$

2.3. Equilibrium Studies. Equilibrium isotherm studies were conducted by agitating $0.5 \mathrm{~g}$ (particle size of $212 \mu \mathrm{m}$ ) of $\mathrm{CH}$ with $50 \mathrm{~mL}$ of zinc solution of $\mathrm{pH} 2$ for 30 minutes at 298, 308, and $318 \mathrm{~K}$. The initial metal concentration ranged from 15 to $100 \mathrm{mgL}^{-1}$. The samples were then centrifuged and analysed as described earlier.

\section{Results and Discussion}

3.1. Effect of Particle Size. The results of experiments conducted on the effect of particle size are summarized in Figure 1. The figure shows that percentage removal increased with decrease in particle size. This could be linked to the fact that equal quantity of a given biosorbent with different mesh sizes would present different numbers of binding sites. It is obvious that the smallest particle size will provide the highest number of active sites due to its high surface area because the larger the particle size, the smaller the surface area and the fewer the number of active sites present.

3.2. Effect of $p H$. The effect of $\mathrm{pH}$ on the biosorption of $\mathrm{Zn}$ (II) by cow hoof is presented in Figure 2. It is obvious from the 


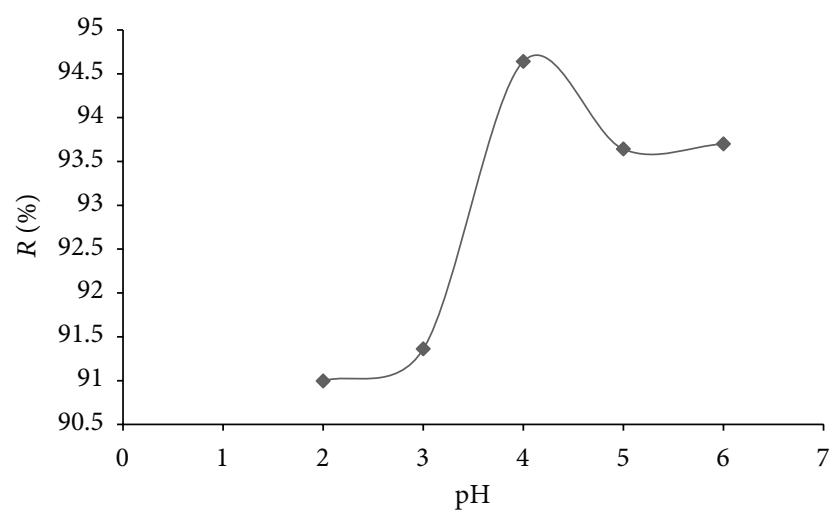

FIGURE 2: Effect of $\mathrm{pH}$ on the sorption removal of zinc by cow hoof.

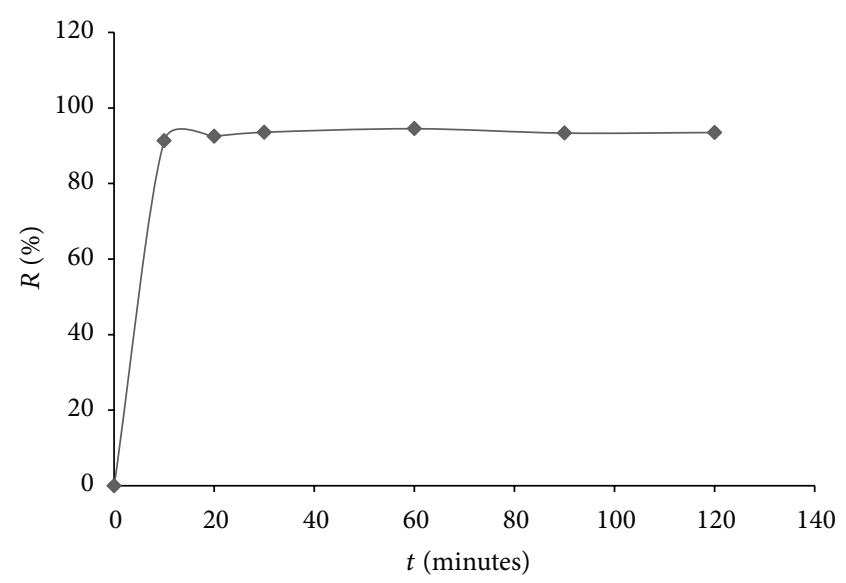

FIGURE 3: Effect of contact time on the removal of zinc by cow hoof.

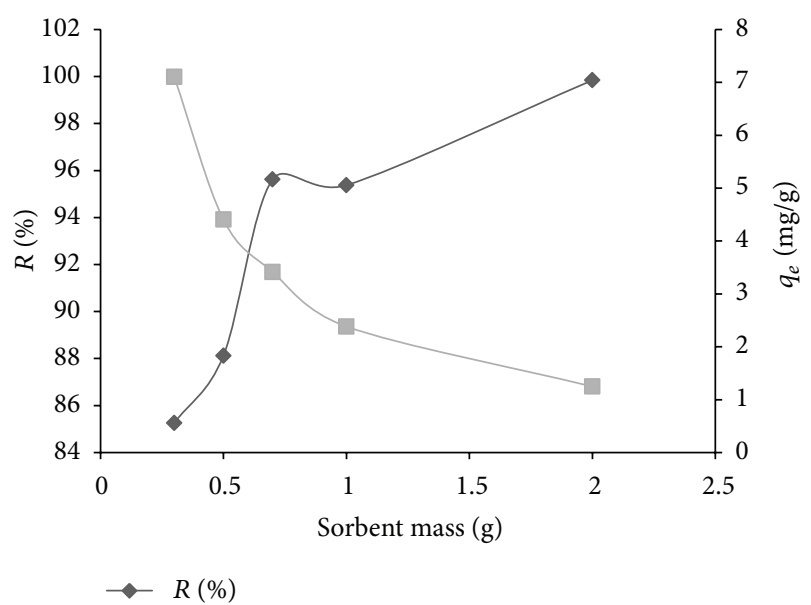

FIGURE 4: Effect of sorbent mass on the removal of zinc by cow hoof.

At low $\mathrm{pH}$, there is high concentration of hydrogen ions; this shifts the equilibrium to the left, thereby decreasing the amount of $\mathrm{Zn}^{2+}$ biosorbed. Apart from this, there is a competition for the active site between the $\mathrm{Zn}^{2+}$ and $\mathrm{H}^{+}$ at low $\mathrm{pH}$ values. But as the $\mathrm{pH}$ increases, the amount of hydrogen ions present will be decreased. This favours the production of more negative ions (i.e., $\mathrm{COO}^{-}$) which enhances the biosorption of $\mathrm{Zn}^{2+}$. At $\mathrm{pH}$ higher than 4 a decrease in the amount of zinc removed was noticed; this could be due to the formation of anionic hydroxide complexes and lower polarity of zinc ions at higher $\mathrm{pH}$ values $[1,21]$. Literature reports have it that maximum uptake of $\mathrm{Zn}^{2+}$ for most biosorbents takes place between $\mathrm{pH} 4$ and $5[1,11,22]$.

3.3. Effect of Contact Time. The result for the effect of contact time on the removal of $\mathrm{Zn}$ by $\mathrm{CH}$ is presented in Figure 3. The result shows that the rate of metal removal occurred rapidly within the first 10 minutes of the biosorption process, and after this the process proceeded slowly. This indicates that most of the biosorption occurs on the surface rather than the pores of the cow hoof [23]. The figure also reveals that maximum uptake (94.5\%) of zinc took place after 60 minutes of agitation, beyond which there was no appreciable increase decrease in biosorption rate. This might be due to saturation of the biosorbent surface with zinc followed by adsorption and desorption after saturation [5].

3.4. Effect of Sorbent Mass. Figure 4 presents the results of the influence of mass of $\mathrm{CH}$ on the percentage removal and the amount of zinc biosorbed at equilibrium $\left(\mathrm{mgg}^{-1}\right)$. It is clear from the figure that the percentage of $\mathrm{Zn}^{2+}$ adsorbed increased gradually (from 85.26 to $98.84 \%$ ) while the uptake capacity in $\mathrm{mgg}^{-1}$ decreased (from 7.1 to $1.25 \mathrm{mgg}^{-1}$ ) with increase in the mass of $\mathrm{CH}$ used. This may be due to increase in the number of binding sites available at high concentrations of the biosorbent.

3.5. Biosorption Kinetics. The biosorption kinetics of the removal of $\mathrm{Zn}^{2+}$ by cow hoof was analysed using Lagergren in the percentage removal of zinc; instead there was a small 
TABLE 1: Kinetic parameters for the biosorption of zinc on $\mathrm{CH}$.

\begin{tabular}{lccccc}
\hline & \multicolumn{2}{c}{ Pseudo-first-order } & \multicolumn{3}{c}{ Pseudo-second-order } \\
$k_{1}\left(\mathrm{~min}^{-1}\right)$ & $q_{e}(\mathrm{th})\left(\mathrm{mgg}^{-1}\right)$ & $q_{e}(\mathrm{ex})\left(\mathrm{mgg}^{-1}\right)$ & $R^{2}$ & $k_{2}\left(\mathrm{gmg}^{-1} \mathrm{~min}^{-1}\right)$ & $q_{e}(\mathrm{th})\left(\mathrm{mgg}^{-1}\right)$ \\
\hline-0.00713 & 0.108 & 4.725 & 0.4472 & 2.565 & $R^{2}$ \\
\hline
\end{tabular}

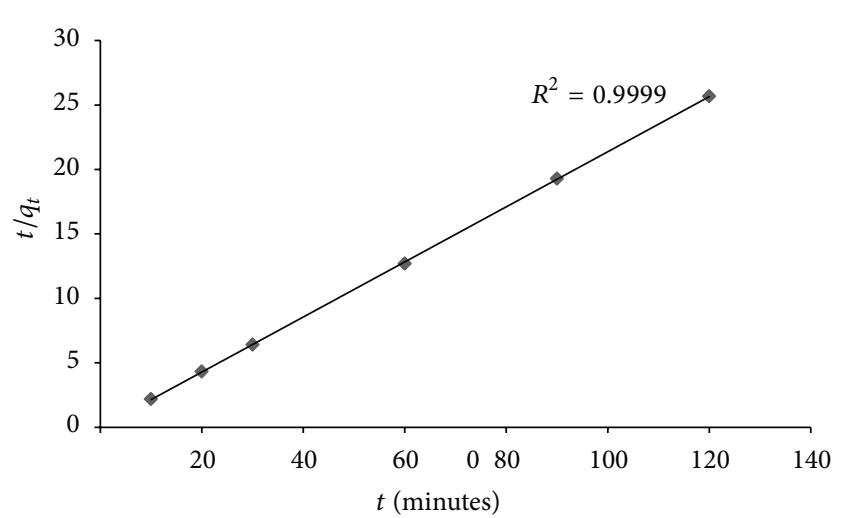

FIGURE 5: Second-order kinetic plot for the removal of zinc by cow hoof, $T=298 \mathrm{~K}, \mathrm{pH}=4$, biosorbent mass $=0.5 \mathrm{~g}$.

first-order and second-order kinetic equations represented by, respectively,

$$
\begin{gathered}
\log \left(q_{e}-q_{t}\right)=\log q_{e}-\frac{k_{1} t}{2.303}, \\
\frac{t}{q_{t}}=\frac{1}{k_{2} q_{e}^{2}}+\frac{1}{q_{e}} t
\end{gathered}
$$

where $k_{1}=$ the rate constant for first-order equation $\left(\mathrm{min}^{-1}\right)$, $q_{e}=$ the amount of metal biosorbed at equilibrium $\left(\mathrm{mgg}^{-1}\right)$, $q_{t}=$ the amount of sorbate biosorbed at time $t\left(\mathrm{mgg}^{-1}\right)$, and $k_{2}$ is the second-order adsorption rate constant $\left(\mathrm{gmg}^{-1} \mathrm{~min}^{-1}\right)$. Straight line graphs were generated for the two equations and the kinetic parameters are listed in Table 1.

The value of the theoretical equilibrium uptake, $q_{e}$ (th), and the experimental value $q_{e}$ (ex) obtained for second-order equation are in good agreement (Table 1). This, coupled with the high correlation coefficient (Table 1 and Figure 5), indicates that the biosorption of zinc onto $\mathrm{CH}$ is better described by the second-order equation suggesting that chemisorption was the rate determining step.

3.6. Biosorption Isotherms. Several isotherm equations are available for equilibrium modelling of adsorption processes. In this study, Langmuir, Freundlich, and DubininRadushkevich (D-R) isotherm models were used to analyse the equilibrium data obtained at 298, 308, and $318 \mathrm{~K}$. The Langmuir equation assumes a monolayer adsorption in which all adsorbed ions do not interact with each other and once a metal ion occupies a site, no further adsorption can take place on that site. The model can take the following linear form:

$$
\frac{C_{e}}{q_{e}}=\frac{1}{K_{L} q_{m}}+\frac{C_{e}}{q_{m}}
$$

where $q_{m}\left(\mathrm{mgg}^{-1}\right)$ is the maximum adsorption capacity and $K_{L}\left(\mathrm{Lmg}^{-1}\right)$ is a constant related to the affinity of binding sites or bonding energy.

Both Freundlich and D-R isotherm models are based on the assumption that adsorption occurs on a heterogeneous surface. The Freundlich model can be expressed linearly as

$$
\log q_{e}=\log K_{f}+\frac{1}{n} \log C_{e},
$$

where $q_{e}\left(\mathrm{mgg}^{-1}\right)$ is the uptake at equilibrium concentration, $C_{e}\left(\mathrm{mgL}^{-1}\right)$, and $K_{f}$ and $1 / n$ are the Freundlich constants related to biosorption capacity and biosorption intensity, respectively. The Dubinin-Radushkevich isotherm can be expressed in the following linear form:

$$
\ln q_{e}=\ln q_{D}-K_{D} \varepsilon^{2}
$$

where $\varepsilon$ is the Polanyi potential $=\mathrm{RT} \ln \left(1+1 / C_{e}\right), q_{D}$ is the biosorption capacity of the biosorbent $\left(\mathrm{mgg}^{-1}\right), K_{D}$ is a constant related to the biosorption energy $\left(\mathrm{moL}^{2} \mathrm{~kJ}^{-2}\right), R$ is the gas constant $\left(\mathrm{kJK}^{-1} \mathrm{moL}^{-1}\right)$, and $T$ is the temperature $(\mathrm{K})$. The mean biosorption energy can be determined from $\mathrm{D}-\mathrm{R}$ model using the following relationship:

$$
E=\left(-2 K_{D}\right)^{-1 / 2}
$$

The magnitude of the energy $E$ is useful for estimating the type of adsorption. If this value is less than $8 \mathrm{~kJ} \mathrm{moL}^{-1}$, the adsorption process is said to be dominated by physical adsorption, between 8 and $16 \mathrm{~kJ} \mathrm{moL}^{-1}$ the process is dominated by ion exchange, and if $E$ is greater than $16 \mathrm{~kJ} \mathrm{moL}^{-1}$ the adsorption process is dominated by a stronger chemical adsorption than ion exchange [5].

The biosorption constants and the correlation coefficients for the three isotherm models are presented in Table 2. The respective maximum adsorption capacities $q_{m}, K_{f}$, and $q_{D}$ for these models increased from 10.93 to $11.58 \mathrm{mgg}^{-1}$, 4.095 to $7.58 \mathrm{~L}^{1 / n} \mathrm{~g}^{-1} \mathrm{mg}^{-1 / n}$, and 7.35 to $11.19 \mathrm{mgg}^{-1}$ when the system temperature was increased from $298 \mathrm{~K}$ to $318 \mathrm{~K}$. This observation indicates that the biosorption process is endothermic. This may be due to the mobility of molecules which increases generally with increase in temperature [24]. The mean biosorption energies computed from D-R model (Table 2) at all temperatures reveal that physisorption dominated the biosorption of zinc on $\mathrm{CH}$, since all values of $E$ are less than 8 . This clearly shows that other biosorption mechanisms may be involved in the removal of $\mathrm{Zn}$ by $\mathrm{CH}$ since kinetic modeling has earlier revealed chemisorption to be the rate determining step.

The $R^{2}$ values for the three models clearly show that Langmuir model described the biosorption process better than the two other models especially at all temperatures. 


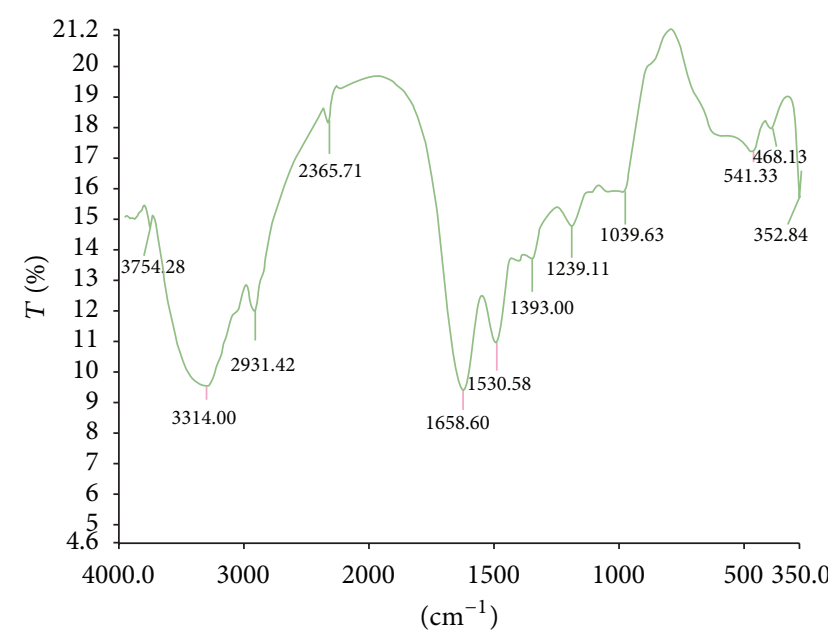

(a)

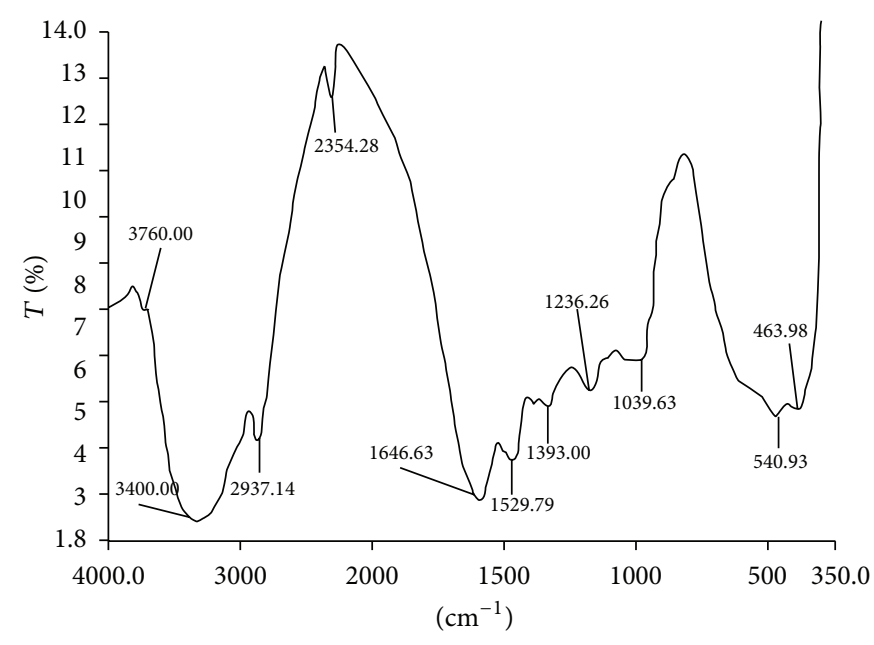

(b)

FIGURE 6: FTIR spectra of (a) unloaded $\mathrm{CH}$ and (b) $\mathrm{Zn}^{2+}$ loaded $\mathrm{CH}$.

TABLE 2: Isotherm parameters for the removal of $\mathrm{Zn}$ (II) by $\mathrm{CH}$ at different temperatures.

\begin{tabular}{lcccc}
\hline \multirow{2}{*}{ Isotherm } & \multirow{2}{*}{ Parameter } & \multicolumn{3}{c}{ Temperature $(\mathrm{K})$} \\
& & 298 & 308 & 318 \\
\hline \multirow{3}{*}{ Langmuir } & $q_{m}\left(\mathrm{mgg}^{-1}\right)$ & 10.93 & 11.53 & 11.58 \\
& $K_{L}\left(\mathrm{Lmg}^{-1}\right)$ & 0.776 & 2.121 & 2.181 \\
& $R^{2}$ & 0.9495 & 0.9774 & 0.9637 \\
\hline \multirow{4}{*}{ Freundlich } & $K_{f}\left(\mathrm{~L}^{1 / n} \mathrm{~g}^{-1} \mathrm{mg}^{-1 / n}\right)$ & 4.095 & 7.413 & 7.58 \\
& $n$ & 2.056 & 1.868 & 1.889 \\
& $R^{2}$ & 0.9014 & 0.7828 & 0.7617 \\
\hline \multirow{4}{*}{ D-R } & $q_{D}\left(\mathrm{mgg}^{-1}\right)$ & 7.35 & 11.05 & 11.19 \\
& $K_{D}\left(\mathrm{moL}^{2} \mathrm{KJ}^{-2}\right)$ & -0.0755 & -0.0574 & -0.0491 \\
& $E\left(\mathrm{KJ} \mathrm{moL}^{-1}\right)$ & 2.57 & 2.951 & 3.191 \\
& $R^{2}$ & 0.8112 & 0.9766 & 0.9441 \\
\hline
\end{tabular}

3.7. Biosorption Thermodynamics. The equilibrium amount of $\mathrm{Zn}$ adsorbed onto the cow hoof at different temperatures was examined to obtain thermodynamic parameters such as Gibbs free energy change $\left(\Delta G^{0}\right)$, enthalpy change $\left(\Delta H^{0}\right)$, and entropy change $\left(\Delta S^{0}\right)$. These were calculated using the following expressions:

$$
\begin{gathered}
K_{e}=\frac{C_{A e}}{C_{e}}, \\
\ln K_{e}=-\frac{\Delta H}{R T}+\frac{\Delta S}{R},
\end{gathered}
$$

where $K_{e}$ is the equilibrium constant, $C_{e}$ is the equilibrium metal ion concentration in solution $\left(\mathrm{mgL}^{-1}\right), C_{A e}$ is the amount of metal ions adsorbed on the biosorbent at equilibrium $\left(\mathrm{mgL}^{-1}\right), T$ is temperature in Kelvin, and $R$ is the gas constant $\left(\mathrm{JmoL}^{-1} \mathrm{~K}^{-1}\right)$. The values of the standard enthalpy change $\left(\Delta H^{0}\right)$ and standard entropy change $\left(\Delta S^{0}\right)$ were calculated from the slope and intercept of the linear
TABLE 3: Thermodynamic parameters for the biosorption of $\mathrm{Zn}$ onto $\mathrm{CH}$ at different temperatures.

\begin{tabular}{lccc}
\hline$T(\mathrm{~K})$ & $\Delta G^{0}\left(\mathrm{~kJ} \mathrm{moL}^{-1}\right)$ & $\Delta H^{0}\left(\mathrm{~kJ} \mathrm{moL}^{-1}\right)$ & $\Delta S^{0}\left(\mathrm{~J} \mathrm{moL}^{-1}\right)$ \\
\hline 298 & -10.14 & 42.792 & 177.61 \\
308 & -11.912 & & \\
318 & -13.687 & & \\
\hline
\end{tabular}

plot of $\ln K_{e}$ against $1 / T$ while the values of $\Delta G^{0}$ at different temperatures were determined using the equation:

$$
\Delta G^{0}=\Delta H^{0}-T \Delta S^{0} .
$$

The values of the different thermodynamic parameters are listed in Table 3. The negative value of $\Delta G^{0}$ is an indication that the process was feasible and spontaneous while the enthalpy of the process confirms the endothermic nature of the biosorption process. The positive value of $\Delta S^{0}$ indicates that there is an increase in the randomness in the system solid/solution interface during the biosorption process. This further indicates that cow hoof has a great affinity for $\mathrm{Zn}^{2+}$ ions and there are some structural changes at $\mathrm{Zn}$ and $\mathrm{CH}$ interface [25].

3.8. FTIR Analysis. The interaction between zinc and the active functional groups on the surface of $\mathrm{CH}$ was studied using FTIR spectroscopic analysis. The FTIR spectrum of cow hoof is shown in Figure 6(a) and a list of the major functional groups on the adsorbent surface before and after $\mathrm{Zn}$ biosorption is shown in Table 4. The following functional groups could be easily identified on the surface of $\mathrm{CH}$ : carbonyl, hydroxyl, amine, amide, aliphatic $\mathrm{C}-\mathrm{H}$ groups, and so forth. Some of the absorption bands for these functional groups were shifted while others were retained after the biosorption of $\mathrm{Zn}^{2+}$. Three prominent bands decrease of functional group can be identified on the cow hoof surface 
TABLE 4: FTIR spectral characteristics of $\mathrm{CH}$ before and after $\mathrm{Zn}$ (II) biosorption.

\begin{tabular}{|c|c|c|c|c|}
\hline IR peak & Frequency $\left(\mathrm{cm}^{-1}\right)$ before adsorption & Frequency $\left(\mathrm{cm}^{-1}\right)$ after adsorption & Difference & Functional group \\
\hline 1 & 3314.00 & 3400 & 86 & Bonded $-\mathrm{OH}$ group \\
\hline 2 & 2931.42 & 2937.14 & 5.72 & Aliphatic C-H groups \\
\hline 3 & 2365.71 & 2354.28 & -11.43 & S-H stretching \\
\hline 4 & 1658.60 & 1646.63 & -11.37 & $\mathrm{C}=\mathrm{O}$ stretching \\
\hline 5 & 1530.58 & 1529.79 & -0.79 & Amino/nitro compound \\
\hline 6 & 1393.00 & 1393.100 & 0 & Nitro compound \\
\hline 7 & 1239.11 & 1236.26 & -2.85 & C-N stretching \\
\hline 8 & 1039.63 & 1039.63 & 0 & $\mathrm{C}-\mathrm{O}$ stretching \\
\hline
\end{tabular}

after biosorption (Figure 6 and Table 4$)$ at $2365.71(-\mathrm{S}-\mathrm{H})$, $1658.6(-\mathrm{C}=\mathrm{O})$, and 1530.58 (amino). This is an indication of the possible involvement of these three functional groups in the biosorption of $\mathrm{Zn}$ onto $\mathrm{CH}$. In comparing the involvement of these functional groups (particularly $\mathrm{C}=\mathrm{O}$ and $\mathrm{S}-\mathrm{H}$ ) in the biosorption of $\mathrm{Zn}$ and the high positive enthalpy of the process, one can assume that chemisorption took a prominent role in the removal of $\mathrm{Zn}(\mathrm{II})$. Therefore, the biosorption of $\mathrm{Zn}$ (II) by powdered cow hooves can be described by both physical and chemical adsorption since the mean energy evaluated from the D-R isotherm model had earlier suggested that the removal of $\mathrm{Zn}$ from aqueous solution using cow hooves was dominated by physisorption.

\section{Conclusions}

The biosorption of $\mathrm{Zn}^{2+}$ on cow hoof was found to be influenced by the different parameters considered. The maximum uptake of $\mathrm{Zn}^{2+}$ occurred under the following conditions: $\mathrm{pH}$ of 4 , particle size $212 \mu \mathrm{m}$, contact time of 60 minutes and biosorbent mass of $2 \mathrm{~g}$. It has been observed that $\mathrm{C}=\mathrm{O}$ and $\mathrm{S}-\mathrm{H}$ functional groups present on the surface of the biosorbent were involved in the removal of zinc ions from aqueous solution. The biosorption process was feasible, spontaneous, and endothermic in nature while the kinetic parameters obviously revealed that the biosorption process followed the pseudo-second-order kinetic model.

\section{References}

[1] L. C. Ajjabi and L. Chouba, "Biosorption of $\mathrm{Cu}^{2+}$ and $\mathrm{Zn}^{2+}$ from aqueous solutions by dried marine green macroalga Chaetomorpha linum," Journal of Environmental Management, vol. 90, no. 11, pp. 3485-3489, 2009.

[2] M. Jain, V. K. Garg, and K. Kadirvelu, "Adsorption of hexavalent chromium from aqueous medium onto carbonaceous adsorbents prepared from waste biomass," Journal of Environmental Management, vol. 91, no. 4, pp. 949-957, 2010.

[3] Y. Bulut and Z. Baysal, "Removal of $\mathrm{Pb}$ (II) from wastewater using wheat bran," Journal of Environmental Management, vol. 78, no. 2, pp. 107-113, 2006.

[4] F. A. Abu Al-Rub, M. H. El-Naas, F. Benyahia, and I. Ashour, "Biosorption of nickel on blank alginate beads, free and immobilized algal cells," Process Biochemistry, vol. 39, no. 11, pp. 17671773, 2004.
[5] M. E. Argun, S. Dursun, C. Ozdemir, and M. Karatas, "Heavy metal adsorption by modified oak sawdust: thermodynamics and kinetics," Journal of Hazardous Materials, vol. 141, no. 1, pp. 77-85, 2007.

[6] B. Volesky and Z. R. Holan, "Biosorption of heavy metals," Biotechnology Progress, vol. 11, no. 3, pp. 235-250, 1995.

[7] K. Vijayaraghavan and Y.-S. Yun, "Bacterial biosorbents and biosorption," Biotechnology Advances, vol. 26, no. 3, pp. 266-291, 2008.

[8] A. Ratnakumari and K. Sobha, "Biosorption of $\mathrm{Cu}^{2+}$ using animal polymers: chick and duck feathers," International Journal of Research in Pharmaceutical and Biomedical Sciences, vol. 3, no. 2, pp. 664-669, 2012.

[9] P. Senthil Kumar, S. Ramalingam, R. V. Abhinaya, S. D. Kirupha, A. Murugesan, and S. Sivanesan, "Adsorption of metal ions onto the chemically modified agricultural waste," Clean-Soil, Air, Water, vol. 40, no. 2, pp. 188-197, 2012.

[10] A. S. A. Prasad, G. Varatharaju, C. Anushri, and S. Dhivyasree, "Biosorption of lead by Pleurotus florida and Trichoderma viride," British Biotechnology Journal, vol. 3, no. 1, pp. 66-78, 2013.

[11] L. Norton, K. Baskaran, and T. McKenzie, "Biosorption of zinc from aqueous solutions using biosolids," Advances in Environmental Research, vol. 8, no. 3-4, pp. 629-635, 2004.

[12] R. J. E. Martins, R. Pardo, and R. A. R. Boaventura, "Cadmium(II) and zinc(II) adsorption by the aquatic moss Fontinalis antipyretica: effect of temperature, $\mathrm{pH}$ and water hardness," Water Research, vol. 38, no. 3, pp. 693-699, 2004.

[13] P. X. Sheng, Y.-P. Ting, J. P. Chen, and L. Hong, "Sorption of lead, copper, cadmium, zinc, and nickel by marine algal biomass: characterization of biosorptive capacity and investigation of mechanisms," Journal of Colloid and Interface Science, vol. 275, no. 1, pp. 131-141, 2004.

[14] C.-Y. Chen, C.-Y. Yang, and A.-H. Chen, "Biosorption of $\mathrm{Cu}(\mathrm{II})$, $\mathrm{Zn}(\mathrm{II}), \mathrm{Ni}(\mathrm{II})$ and $\mathrm{Pb}$ (II) ions by cross-linked metal-imprinted chitosans with epichlorohydrin," Journal of Environmental Management, vol. 92, no. 3, pp. 796-802, 2011.

[15] E. Yalcin, K. Cavusoglu, and K. Kinalıoglu, "Biosorption of $\mathrm{Cu}^{2+}$ and $\mathrm{Zn}^{2+}$ by raw and autoclaved Rocellap Hycopsi," Journal of Environmental Sciences, vol. 22, no. 3, pp. 367-373, 2010.

[16] C. Yang, J. Wang, M. Lei, G. Xie, G. Zeng, and S. Luo, "Biosorption of zinc(II) from aqueous solution by dried activated sludge," Journal of Environmental Sciences, vol. 22, no. 5, pp. 675-680, 2010.

[17] J. C. Igwe, D. N. Ogunewe, and A. A. Abia, "Competitive adsorption of $\mathrm{Zn}$ (II), $\mathrm{Cd}$ (II) and $\mathrm{Pb}$ (II) ions from aqueous and non- aqueous solution by maize cob and husk," African Journal of Biotechnology, vol. 4, no. 10, pp. 1113-1116, 2005. 
[18] R. Souag, D. Touaibia, B. Benayada, and A. Boucenna, "Adsorption of heavy metals $(\mathrm{Cd}, \mathrm{Zn}$ and $\mathrm{Pb}$ ) from water using keratin powder prepared from Algerien sheep hoofs," European Journal of Scientific Research, vol. 35, no. 3, pp. 416-425, 2009.

[19] T. W. Tee and A. R. M. Khan, "Removal of lead, cadmium and zinc by waste tea leaves," Environmental Technology Letters, vol. 9, no. 11, pp. 1223-1232, 1988.

[20] A. Sarı and M. Tuzen, "Biosorption of cadmium(II) from aqueous solution by red algae (Ceramium virgatum): equilibrium, kinetic and thermodynamic studies," Journal of Hazardous Materials, vol. 157, no. 2-3, pp. 448-454, 2008.

[21] Y. P. Kumar, P. King, and V. S. R. K. Prasad, "Removal of copper from aqueous solution using Ulva fasciata sp.-A marine green algae," Journal of Hazardous Materials, vol. 137, no. 1, pp. 367373, 2006.

[22] B. Nasernejad, T. E. Zadeh, B. B. Pour, M. E. Bygi, and A. Zamani, "Camparison for biosorption modeling of heavy metals (Cr (III), Cu (II), Zn (II)) adsorption from wastewater by carrot residues," Process Biochemistry, vol. 40, no. 3-4, pp. 13191322, 2005.

[23] S. Al-Asheh, F. Banat, and D. Al-Rousan, "Beneficial reuse of chicken feathers in removal of heavy metals from wastewater," Journal of Cleaner Production, vol. 11, no. 3, pp. 321-326, 2003.

[24] N. Nasuha, B. H. Hameed, and A. T. M. Din, "Rejected tea as a potential low-cost adsorbent for the removal of methylene blue," Journal of Hazardous Materials, vol. 175, no. 1-3, pp. 126-132, 2010.

[25] Y.-S. Ho, "Removal of copper ions from aqueous solution by tree fern," Water Research, vol. 37, no. 10, pp. 2323-2330, 2003. 

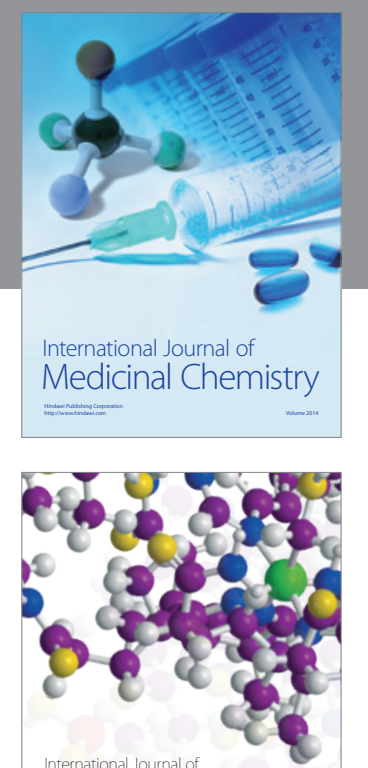

\section{Carbohydrate} Chemistry

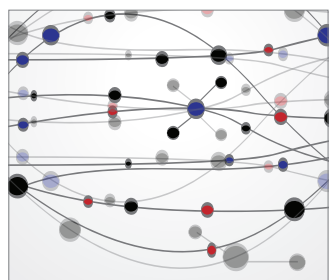

The Scientific World Journal
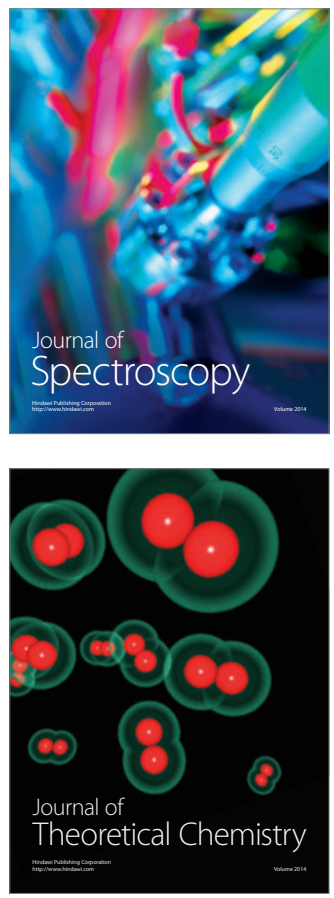
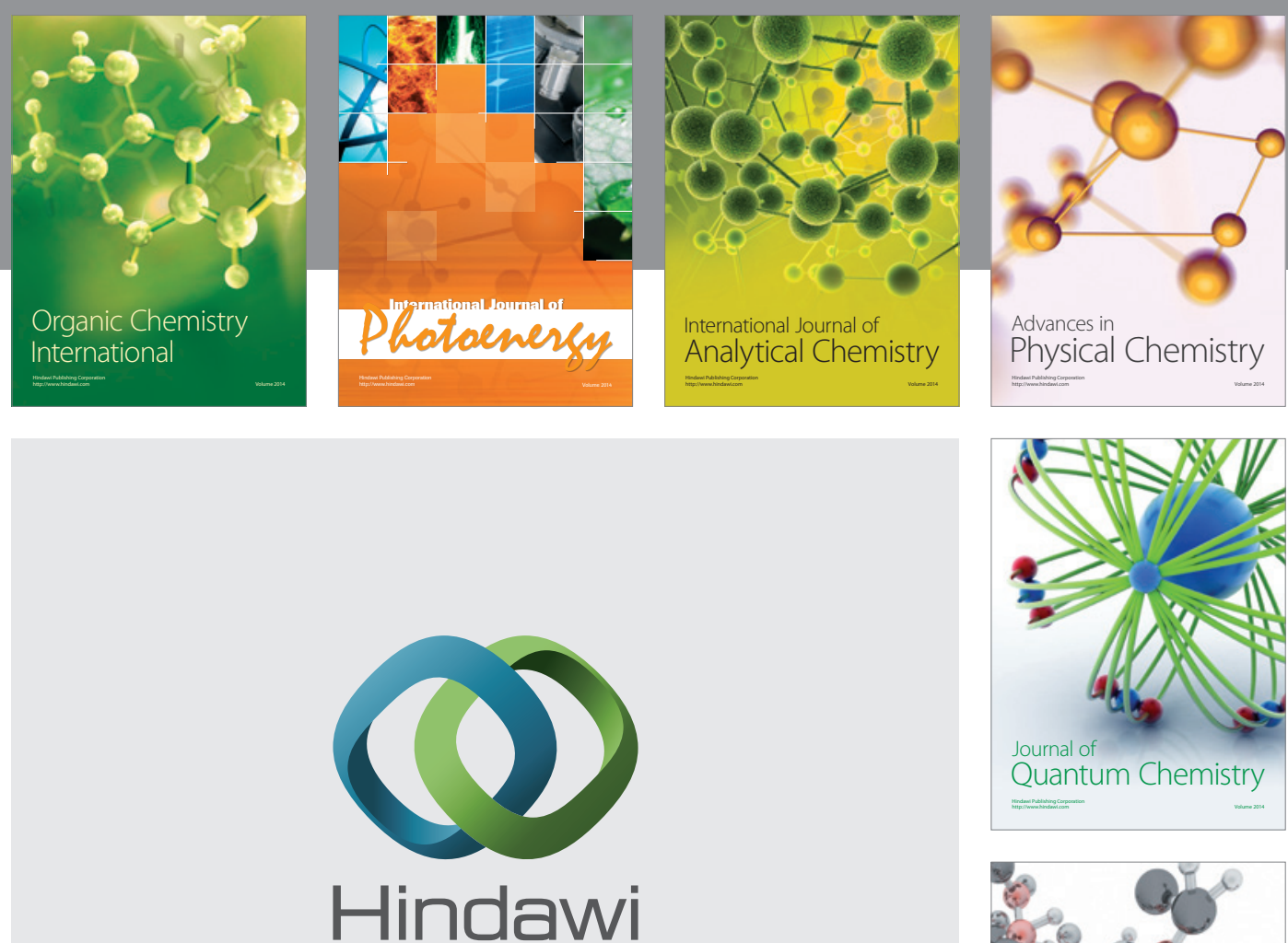

Submit your manuscripts at

http://www.hindawi.com

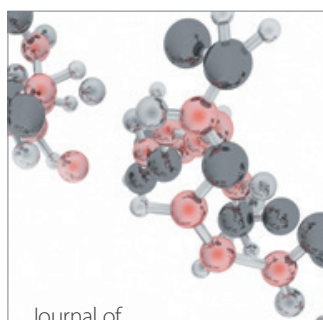

Analytical Methods

in Chemistry

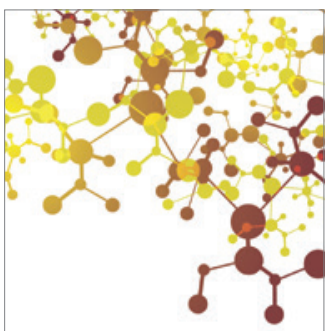

Journal of

Applied Chemistry

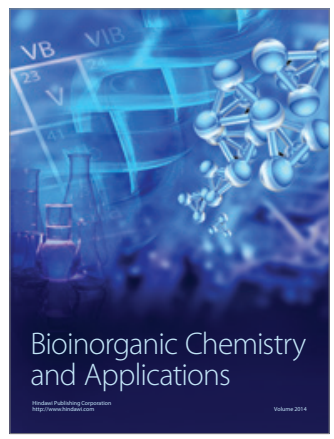

Inorganic Chemistry
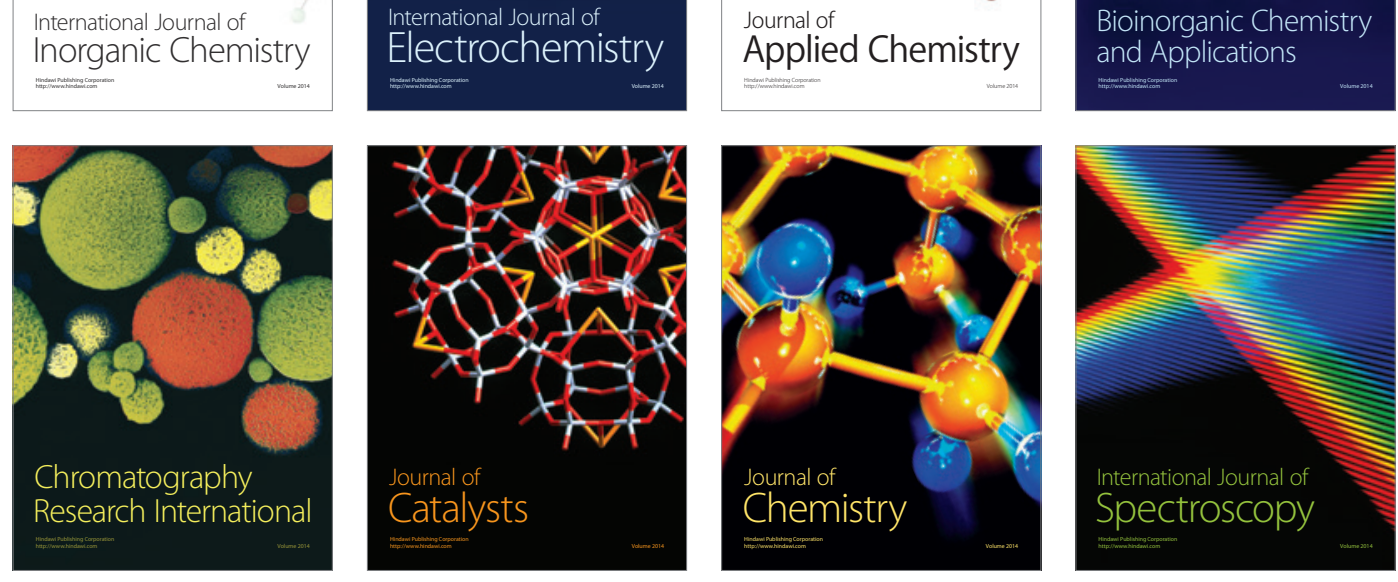